\title{
The Prevalance of Gastrointestinal Tract Protozoa Using Fecal Examination in Local Chicken(Gallus domesticus) Located in Kramat Village, District of Bangkalan, Bangkalan Regency
}

\author{
Prevalensi Protozoa Saluran Pencernaan Melalui Pemeriksaan feses Pada Ayam \\ Buras (Gallus domesticus) di Desa Kramat Kecamatan Bangkalan Kabupaten Bangkalan
}

\author{
${ }^{1)}$ Talita Yuanda Reksa, ${ }^{2}$ Poedji Hastutiek, ${ }^{3)}$ Hana Eliyani, ${ }^{2)}$ Kusnoto, ${ }^{2)}$ Mufasirin \\ ${ }^{1)}$ Mahasiswa, ${ }^{2)}$ Department of Parasitology Veterinary, ${ }^{3}$ Department of Anatomi Veteriner. Faculty of \\ Veterinary Medicine, Universitas Airlangga
}

\begin{abstract}
The aim of this research is to identify the prevalence of gastrointestinal track protozoa in local chicken (Gallus domesticus) located in Kramat Village, District of Bangkalan, Bangkalan Regency using fecal examination. The number of sample used were 140 including 70 samples from rice fields location and 70 samples from fisheries location. The result showed that $54(38.6 \%)$ local chickens were infected by species of Eimeria; E. acervulina (2.5\%), E. brunetti (22.8\%), E. maxima (46.8\%), E. mitis (1.3\%), E. necatrix (22.8\%), E. praecox (2.5\%), and E. tenella (1.3\%). The result was made of $16(22.9 \%)$ local chickens in rice fields location and 38 (54.3\%) local chickens in fisheries location. The infection of Eimeria sp. on male local chickens were $24(34.3 \%)$ while on the female local chickens were 30 (42.9\%). Chi Square Test showed that there was a highly significant difference toward the prevalence in rice fields and fishery locations $(\mathrm{p}<\mathrm{0.01})$, but there was no significant difference toward the prevalence of male and female local chickens ( $\mathrm{p}>0.05)$.
\end{abstract}

Keywords : prevalence, gastrointestinal track protozoa, local chicken, fecal examination

\section{Pendahuluan}

Ayam buras merupakan salah satu ternak unggas yang berperan bagi kehidupan masyarakat pedesaan sebagai sumber daging, telur, dan tambahan pendapatan (Solihati dkk., 2006). Ayam buras memiliki keunggulan dibandingkan dengan ayam ras, yaitu memiliki daya tahan tubuh yang lebih baik, sehingga lebih tahan terhadap penyakit. Di pedesaan ayam buras dipelihara dengan sistem pemeliharaan ekstensif, yaitu ayam buras dibiarkan berkeliaran untuk mencari makan. Menurut Rohaeni dkk. (2004), sistem pemeliharaan ekstensif memperbesar kemungkinan ayam buras terserang penyakit.

Penyakit yang sering menyerang ayam buras salah satunya disebabkan oleh protozoa saluran pencernaan (Yuwono, 2013). Kejadian infeksi protozoa saluran pencernaan telah banyak dilaporkan di berbagai daerah. Simamora (2017) melaporkan bahwa infeksi protozoa saluran pencernaan pada ayam buras di Wilayah Bukit Jimbaran Badung disebabkan oleh Eimeria tenella sebesar $44,5 \%$. Penelitian yang dilakukan Jamil et al. (2016) melaporkan bahwa prevalensi infeksi Eimeria sp. pada ayam di Pakistan sebesar 44\%. Nagwa et al. (2013) juga melaporkan prevalensi Eimeria sp. yang menginfeksi ayam di Gharbia sebesar 62,3\%. Hal ini menunjukkan bahwa tingkat kejadian penyakit yang disebabkan oleh protozoa saluran pencernaan pada ayam cukup tinggi.

Infeksi yang disebabkan oleh Eimeria sp. sangat infeksius dan fatal pada ayam. Protozoa ini merusak epitel usus yang menyebabkan diare berdarah (Jamil et al., 2016). Kejadian infeksi protozoa saluran pencernaan banyak menyerang ayam betina dibandingkan dengan ayam jantan. Hal ini disebabkan karena daya tahan tubuh ayam betina lebih rentan terhadap penyakit (Hidayati dan Prastowo, 2004). Infeksi protozoa saluran pencernaan pada ayam buras tidak selalu menunjukkan gejala klinis, namun pada infeksi yang berat dapat menimbulkan kerugian (Soulsby, 1986). Kerugian dalam aspek 
ekonomi dapat berupa peningkatan biaya pengobatan, penurunan produktivitas, penurunan efisiensi reproduksi, dan kematian (Triakoso, 2009).

Berdasarkan survei yang dilakukan di Desa Kramat Kecamatan Bangkalan Kabupaten Bangkalan pada bulan Juli 2017 diperoleh informasi bahwa pernah terjadi kematian ayam buras secara masal yang belum diketahui penyebabnya. Ayam buras di desa ini dipeliharan secara semi intensif di dua lokasi yaitu persawahan dan pertambakan. Kondisi lingkungan di pertambakan lebih lembap, sehingga memungkinakan terjadi infeksi yang lebih tinggi dibandingkan dengan persawahan.

Sejauh ini belum ada penelitian yang melaporkan prevalensi protozoa saluran pencernaan pada ayam buras di Desa Kramat Kecamatan Bangkalan Kabupaten Bangkalan. Penelitian ini perlu dilakukan untuk mengetahui jenis dan prevalensi protozoa saluran pencernaan pada ayam buras jantan dan betina di lokasi persawahan dan lokasi pertambakan, sehingga bermanfaat dalam usaha pencegahan dan pengobatan penyakit yang disebabkan oleh protozoa saluran pencernaan pada ayam buras.

\section{Metode Penelitian}

Sampel yang digunakan dalam penelitian ini adalah 70 sampel dari lokasi persawahan yang terdiri dari 35 sampel feses ayam buras jantan dan 35 sampel feses ayam buras betina dan 70 sampel dari lokasi pertambakan yang terdiri dari 35 sampel feses ayam buras jantan dan 35 sampel feses ayam buras betina. Bahan yang digunakan larutan kalium bikromat 2,5\% dan larutan gula jenuh. Alat yang digunakan pot sampel, sendok plastik, kertas label, spidol, gelas, pengaduk, penyaring, pipet tetes, kaca obyek, kaca penutup, tabung sentrifus, alat sentrifus, mikriskop, dan optilab. Sampel diperiksa menggunakan metode sadimentasi dan metode apung, sampel yang positif difoto dan diukur menggunakan optilab.

Data hasil pemeriksaan laboratorium protozoa saluran pencernaan pada ayam buras di Desa Kramat Kecamatan Bangkalan Kabupaten Bangkalan dianalisis menggunakan Chi Square Test pada SPSS versi 23 untuk mengetahui perbedaan prevalensi infeksi protozoa saluran pencernaan pada ayam buras jantan dan betina di lokasi persawahan dan lokasi pertambakan.

\section{Hasil dan Penelitian \\ Jenis Protozoa Saluran Pencernaan Ayam Buras}

Berdasarkan hasil pemeriksaan laboratorium terhadap 140 sampel feses ayam buras dari lokasi persawahan dan lokasi pertambakan di Desa Kramat Kecamatan Bangkalan Kabupaten Bangkalan dengan menggunakan metode sedimentasi dan apung diperoleh hasil bahwa 54 ekor ayam buras dinyatakan positif terinfeksi satu jenis protozoa saluran pencernaan yaitu Eimeria sp., hasil tersebut dapat dilihat pada Tabel 1 dan Gambar 1.

Tabel 1. Jenis Protozoa Saluran Pencernaan pada Ayam Buras di Desa Kramat Kecamatan Bangkalan Kabupaten Bangkalan

\begin{tabular}{cccc}
\hline $\begin{array}{c}\text { Jenis } \\
\text { Kelamin }\end{array}$ & $\begin{array}{c}\text { Sampel } \\
\text { Positif }\end{array}$ & $\begin{array}{c}\text { Jumlah } \\
\text { Sampel }\end{array}$ & $\begin{array}{c}\text { Jenis } \\
\text { Protozoa }\end{array}$ \\
\hline Jantan & 24 & 70 & Eimeria \\
Betina & 24 & 70 & sp. \\
\hline Total & 54 & 140 & \\
\hline
\end{tabular}

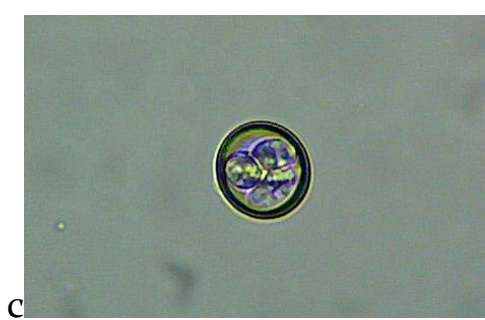

Gambar 1. Stadium ookista Eimeria sp. pada pemeriksaan feses ayam buras (G. domesticus) menggunakan mikroskop Nikon E 100 perbesaran 400x.

Pada identifikasi jenis protozoa hanya ditemukan satu jenis protozoa yang menginfeksi saluran pencernaan ayam buras di Desa Kramat Kecamatan Bangkalan Kabupaten Bangkalan. Jenis protozoa tersebut yaitu Eimeria sp. dengan bentuk dan ukuran yang beragam. Identifikasi Eimeria sp. ditentukan dengan adanya stadium ookista dengan ciri-ciri terdapat empat sporokista yang dilengkapi dengan dua sporozoit (Taylor et al., 2007). Pada penelitian ini hanya dapat ditemukan protozoa Eimeria sp. kemungkinan karena metode pemeriksaan yang digunakan adalah pemeriksaan feses dengan metode sedimentasi dan apung, sehingga protozoa saluran pencernaan atas dan protozoa saluran pencernaan bawah lain tidak dapat ditemukan. Protozoa saluran pencernaan atas dapat ditemukan apabila dilakukan swab kerongkongan serta menggunakan metode pewarnaan khusus agar protozoa dapat terlihat 
jelas pada pengamatan mikroskopis (Levine, 1995).

Stadium ookista Eimeria sp. dari feses ayam buras, ditemukan baik di lokasi persawahan maupun lokasi pertambakan. Hasil pengukuran ookista dari sampel feses ayam buras di lokasi persawahan menunjukkan bentuk dan ukuran yang beragam mulai ukuran terbesar 51,7 × 37,8 $\mu \mathrm{m}$ sampai ukuran terkecil 16,9 × 14,3 $\mu \mathrm{m}$. Hasil tersebut dapat dilihat pada Gambar 2.
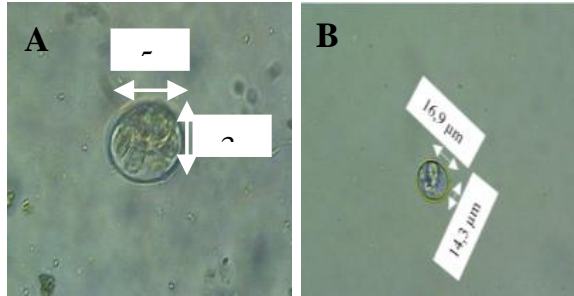

Gambar 2. Hasil pengukuran Eimeria sp. di lokasi persawahan dengan perbesaran 400x, (A) ukuran terbesar (B) ukuran terkecil.

Hasil pengukuran ookista dari sampel feses ayam buras di lokasi pertambakan menunjukkan bentuk dan ukuran yang beragam mulai ukuran terbesar 54,3 $\times 35,8 \mu \mathrm{m}$ sampai ukuran terkecil 23,8 $\times 17,8 \mu \mathrm{m}$. Hasil tersebut dapat dilihat pada Gambar 3 .

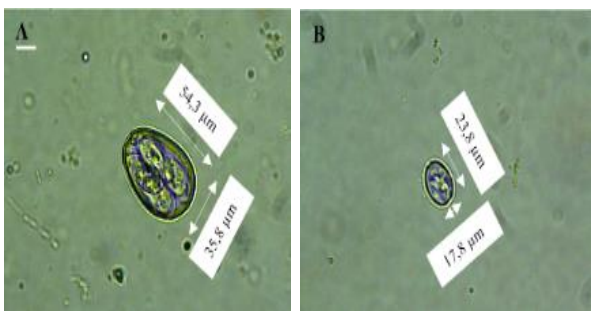

Gambar 3. Hasil pengukuran Eimeria sp. di lokasi pertambakan dengan perbesaran 40ox, (A) ukuran terbesar (B) ukuran terkecil.

Keberagaman bentuk dan ukuran ookista menunjukkan kemungkinan spesies yang ditemukan adalah E. acervulina (2,5\%), E. brunetti (22,8\%), E. maxima (46,8\%), E. mitis $(1,3 \%)$, E. necatrix $(22,8 \%)$, E. praecox $(2,5 \%)$, dan E. tenella $(1,3 \%)$. E. maxima paling banyak ditemukan di lokasi persawahan dan lokasi pertambakan yaitu 37, E. brunetti dan E. necatrix masing-masing 18, E. acervulina dan E. praecox masing-masing 2, sedangkan $E$. mitis dan $E$. tenella paling sedikit ditemukan yaitu masingmasing 1. E. mitis hanya ditemukan di lokasi persawahan, sedangkan $E$. tenella hanya ditemukan di lokasi pertambakan. Hasil tersebut dapat dilihat pada Tabel 2.
Tabel 2. Spesies Eimeria pada Ayam Buras di Lokasi Persawahan dan Lokasi Pertambakan

\begin{tabular}{|c|c|c|c|}
\hline \multirow[b]{2}{*}{$\begin{array}{l}\text { Spesies } \\
\text { Eimeria }\end{array}$} & \multicolumn{2}{|c|}{ Jumlah } & \multirow[b]{2}{*}{ Total } \\
\hline & $\begin{array}{c}\text { Persawa } \\
\text { han }\end{array}$ & $\begin{array}{c}\text { Perta } \\
\text { mbaka } \\
\mathrm{n}\end{array}$ & \\
\hline E. acervulina & 1 & 1 & $2(2,5 \%)$ \\
\hline E. brunetti & 6 & 12 & $18(22,8 \%)$ \\
\hline E. maxima & 9 & 28 & $37(46,8 \%)$ \\
\hline E. mitis & 1 & o & $1(1,3 \%)$ \\
\hline E. necatrix & 2 & 16 & $18(22,8 \%)$ \\
\hline E. praecox & 1 & 1 & $2(2,5 \%)$ \\
\hline E. tenella & o & 1 & $1(1,3 \%)$ \\
\hline
\end{tabular}

Jenis Eimeria yang ditemukan berbeda dengan penelitian Jamil et al. (2016) yang hanya menemukan empat spesies mulai prevalensi tertinggi sampai prevalensi terendah yaitu $E$. mitis (31,82\%), E. maxima (31,06\%), E. tenella $(24,24 \%)$, dan E. necatrix $(12,88 \%)$ yang menginfeksi ayam di Dera Ismail Khan Pakistan kemungkinan karena letak geografis yang berbeda. Menurut Badan Pusat Statistika Kabupaten Bangkalan (2016), Desa Kramat berada pada ketinggian o-20 $\mathrm{m}$ dpl dengan kondisi yang subur, sedangkan Dera Ismail Khan Pakistan berada pada ketinggian $175 \mathrm{~m}$ dpl dengan kondisi yang gersang. Perbedaan kondisi tersebut kemungkinan mempengaruhi perkembangan berbagai spesies Eimeria.

Menurut Soulsby (1986), E. tenella dan E. necatrix merupakan spesies yang paling patogen pada ayam, E. maxima dan E. brunetti memiliki patogenitas sedang, sedangkan E. acervulina, $E$. mitis, dan E. praecox tidak patogen. Pada penelitian ini prevalensi $E$. tenella $(1,3 \%)$ sangat rendah bila dibandingkan dengan penelitian yang dilakukan oleh Yulian (2017) yaitu 20\%. Hal ini kemungkinan karena jenis ayam yang diteliti adalah ayam petelur, sedangkan dalam penelitian ini adalah ayam buras, sehingga memiliki daya tahan tubuh yang lebih kuat.

Prevalensi E. necatrix (22,8\%) dalam penelitian ini lebih tinggi dibandingkan dengan penelitian Hadipour et al. (2011) yaitu 12\% kemungkinan karena Desa Kramat merupakan daerah yang lembap, sedangkan Shiraz Iran merupakan daerah yang memiliki kelembapan sedang. Menurut Adhikari et al. (2008), prevalensi Eimeria sp. paling tinggi terjadi pada kondisi yang lembap.

Prevalensi E. maxima (37\%) lebih tinggi dibandingkan dengan penelitian Gyorke et al. (2013) yaitu 22\%. Hal ini kemungkinan karena ayam pada penelitian ini dipelihara secara tradisional, sedangkan pada penelitian Gyorke et al. (2013) ayam dipelihara dalam peternakan, 
sehingga kondisi lingkungan di sekitar kandang lebih bersih dibandingkan dengan ayam di Desa Kramat.

Prevalensi E. brunetti (22,8\%) jauh lebih tinggi dibandingkan dengan penelitian Jadhav dan Nikam (2014) yaitu 2,45\% kemungkinan karena penelitian dilakukan pada ayam di rumah potong, sehingga kondisi lingkungan di sekitar rumah potong lebih bersih dibandingkan dengan Desa Kramat. Menurut Azmy dkk. (2015), ookista akan berkembang baik pada kondisi lingkungan yang kotor.

Prevalensi E. acervulina (2,5\%) lebih tinggi dibandingkan dengan penelitian Kaboudi et al. (2016) yaitu $1.5 \%$ kemungkinan karena perbedaan temperatur lingkungan saat pengambilan sampel. Pada penelitian Kaboudi et al. (2015) sampel diambil saat temperatur lingkungan mencapai $40^{\circ} \mathrm{C}$, sedangkan pada penelitian ini sampel diambil saat musim hujan, sehingga temperatur lingkungan lebih rendah. Menurut Shirley et al. (2007), temperatur mempengaruhi perkembangan ookista sehingga menjadi infektif.

Prevalensi E. mitis (1,3\%) jauh lebih rendah dibandingkan dengan penelitian yang dilakukan Sun et al. (2009) yaitu 60\% kemungkinan karena dalam penelitian ini ayam buras dilepas di lingkungan, sedangkan penelitian Sun et al. (2009) menggunakan ayam broiler pada peternakan, sehingga penularan infeksi ookista infektif lebih mudah terjadi.

Prevalensi E. praecox (2,5\%) jauh lebih rendah dibandingkan dengan penelitian Kimminau (2015) yaitu $79 \%$ kemungkinan karena ayam dalam penelitian ini sudah berumur lebih dari 6 bulan, sedangkan dalam penelitian Kimminau (2015) ayam berumur 6 minggu, sehingga daya tahan tubuh ayam dalam penelitian ini lebih kuat.

Prevalensi Eimeria sp. dalam penelitian ini (38,6\%) lebih rendah dibanding dengan penelitian yang dilakukan oleh Simamora dkk. (2017) di Wilayah Bukit Jimbaran Badung (44,5\%). Perbedaan prevalensi yang diperoleh kemungkinan disebabkan oleh beberapa faktor antara lain umur, ras, perbedaan letak geografis, musim, sistem pemeliharaan, temperatur, curah hujan, kondisi kelembaban udara, dan stress yang bisa menurunkan daya tahan tubuh ayam. Prevalensi Eimeria sp. di Desa Kramat Kecamatan Bangkalan Kabupaten Bangkalan lebih rendah kemungkinan karena ayam buras yang diperiksa sudah dewasa, sehingga memiliki daya tahan tubuh yang lebih baik dibandingkan dengan ayam buras di Wilayah Bukit Jimbaran Badung.

Menurut Simamora dkk. (2017) infeksi Eimeria sp. sering menyerang ayam yang berumur 3 sampai 6 minggu karena daya tahan tubuh yang masih lemah, namun jarang menyerang ayam yang berumur kurang dari 3 minggu. Ayam yang berumur kurang dari 3 minggu belum menghasilkan banyak tripsin dan garam empedu sehingga proses keluarnya sporozoit dari ookista tidak terjadi. Hal ini sesuai dengan pernyataan Soulsby (1986) bahwa dinding ookista akan pecah karena kontraksi ventrikulus, sehingga sporokista keluar dan masuk ke dalam usus halus. Di dalam lumen usus halus sporokista akan pecah karena aktivitas tripsin dan garam empedu, sehingga sporozoit keluar dan masuk ke dalam epitel usus yang selanjutnya mengalami proses skizogoni yang menyebabkan epitel usus ruptur dan pembuluh darah di sekitar epitel usus pecah, sehingga terjadi diare berdarah (Kimminau, 2015).

Pada pemeriksaan feses menggunakan metode sedimentasi dan metode apung, ookista dapat ditemukan pada kedua metode atau pada salah satu metode saja. Hal ini mungkin disebabkan karena berat jenis ookista yang berbeda. Ookista dengan berat jenis yang tinggi dapat ditemukan pada metode sedimentasi, sedangkan ookista dengan berat jenis rendah dapat ditemukan pada metode apung (Levine, 1995).

Cryptosporidium sp. tidak ditemukan dalam penelitian ini kemungkinan karena larutan gula jenuh yang digunakan adalah gula biasa, sedangkan Cryptosporidium sp. akan terlihat apabila dilakukan pemeriksaan dengan metode apung menggunakan larutan gula sukrosa jenuh. Menurut Bowman (2014) dinding Cryptosporidium sp. akan berpendar kemerah mudaan apabila diperiksa dengan metode apung menggunakan gula sukrosa jenuh karena adanya aberasi kromatik pada larutan gula sukrosa jenuh dan bersifat hipertonis.

\section{Prevalensi Protozoa Saluran Pencernaan Ayam Buras di Lokasi Persawahan dan Lokasi Pertambakan \\ Berdasarkan pemeriksaan 140 sampel dari} lokasi persawahan dan pertambakan diperoleh hasil sebanyak $54(38,6 \%)$ ekor ayam buras dinyatakan positif terinfeksi Eimeria sp. yang terdiri dari $16 \quad(22,9 \%)$ ekor dari lokasi persawahan dan $38(54,3 \%)$ ekor dari lokasi 
pertambakan. Hasil tersebut dapat dilihat pada Tabel 3.

Tabel 3. Prevalensi Protozoa Saluran Pencernaan pada Ayam Buras di Lokasi Persawahan dan Lokasi Pertambakan

\begin{tabular}{ccccc}
\hline Lokasi & \multicolumn{2}{c}{ Eimeria sp. } & \multirow{2}{*}{ Total } & Nilai \\
\cline { 2 - 3 } Pemeliharaan & Positif & Negatif & & p \\
\hline \multirow{2}{*}{ Persawahan } & 16 & 54 & \multirow{2}{*}{70} & \\
& $(22,9 \%)$ & $(77,1 \%)$ & & \\
Pertambakan & 38 & 32 & & \\
& $(54,3 \%)$ & $(45,7 \%)$ & 70 & 0,000 \\
\hline
\end{tabular}

Hasil analisis Chi Square Test terhadap prevalensi infeksi Eimeria sp. pada ayam buras di lokasi persawahan dan lokasi pertambakan menunjukkan bahwa infeksi tersebut bernilai sangat signifikan $(\mathrm{p}<\mathrm{o}, \mathrm{ol})$. Hal ini berarti ayam buras yang dipelihara di lokasi pertambakan memiliki proporsi yang lebih tinggi terhadap infeksi Eimeria sp. dibandingkan dengan lokasi persawahan. Hasil tersebut disajikan dalam diagram seperti terlihat pada Gambar 4.

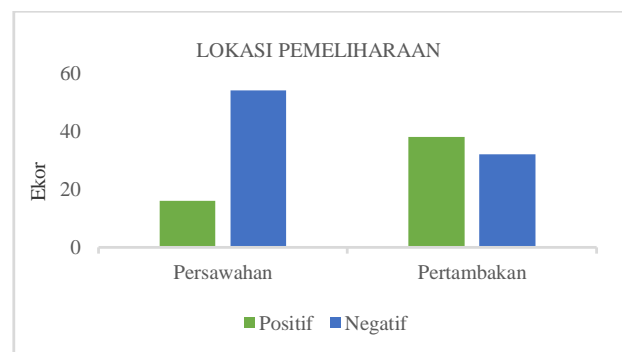

Gambar 4. Diagram prevalensi protozoa saluran pencernaan pada ayam buras di lokasi persawahan dan lokasi pertambakan.

Infeksi Eimeria sp. pada ayam buras di lokasi persawahan lebih rendah dibandingkan lokasi pertambakan. Hal ini kemungkinan karena kondisi lingkungan di lokasi persawahan memiliki kelembapan yang lebih rendah dibandingkan dengan lokasi pertambakan. Lokasi persawahan memiliki lingkungan yang lebih terang dibandingkan lokasi pertambakan karena lokasi tersebut terdiri dari persawahan dengan beberapa tanaman yang kondisinya tidak rimbun dibandingkan dengan lokasi pertambakan, sehingga lokasi tersebut mendapat cahaya yang lebih baik. Kondisi lingkungan tersebut dapat menyebabkan ookista di luar induk semang lebih cepat mati (Salfina, 1995).

Pada lokasi pertambakan infeksi Eimeria sp. lebih tinggi daripada lokasi persawahan. Hal ini kemungkinan karena kondisi lingkungan di lokasi pertambakan lebih lembap dibandingkan dengan kondisi lingkungan di lokasi persawahan. Lokasi pertambakan terdiri dari daerah tambak dan rawa dengan jarak yang cukup dekat dengan pemukiman penduduk, sehingga memungkinkan ayam buras yang dipelihara secara semi intensif untuk berkeliaran di daerah yang basah dan lembap. Lokasi pertambakan memiliki kondisi yang lebih rimbun dibandingkan dengan lokasi persawahan, sehingga lokasi ini mendapatkan cahaya yang tidak lebih terang daripada lokasi persawahan. Kondisi lingkungan tersebut merupakan kondisi yang mendukung ookista untuk bersporulasi dan bertahan lama di lingkungan (Salfina, 1995).

\section{Prevalensi Protozoa Saluran Pencernaan Ayam Buras Jantan dan Betina}

Berdasarkan hasil pemeriksaan 140 sampel feses ayam buras di lokasi persawahan dan pertambakan diperoleh $24(34,3 \%)$ ekor ayam buras jantan positif terinfeksi Eimeria sp., sedangkan ayam buras betina yang terinfeksi sebanyak $30(42,9 \%)$ ekor. Hasil tersebut dapat dilihat pada Tabel 4 dan Gambar 5.

Tabel 4. Prevalensi Protozoa Saluran Pencernaan pada Ayam Buras Jantan dan Betina

\begin{tabular}{|c|c|c|c|c|}
\hline \multirow{2}{*}{$\begin{array}{c}\text { Jenis } \\
\text { Kelamin }\end{array}$} & \multicolumn{2}{|c|}{ Eimeria sp. } & \multirow{2}{*}{ Total } & \multirow{2}{*}{$\begin{array}{c}\text { Nilai } \\
\text { p }\end{array}$} \\
\hline & Positif & Negatif & & \\
\hline Jantan & $\begin{array}{c}24 \\
(34,3 \%)\end{array}$ & $\begin{array}{c}46 \\
(65,7 \%)\end{array}$ & 70 & \multirow{2}{*}{0,385} \\
\hline Betina & $\begin{array}{c}30 \\
(42,9 \%)\end{array}$ & $\begin{array}{c}40 \\
(57,1 \%)\end{array}$ & 70 & \\
\hline
\end{tabular}

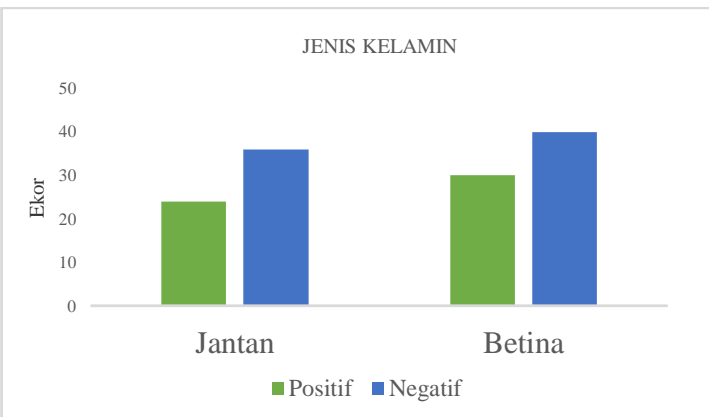

Gambar 5. Diagram prevalensi infeksi protozoa saluran pencernaan pada ayam buras jantan dan betina.

Analisis Chi Square Test terhadap prevalensi infeksi Eimeria sp. pada ayam jantan dan betina menunjukkan hasil yang tidak signifikan $(p>0,05)$. Hal tersebut berarti baik ayam buras jantan maupun betina yang dipelihara di lokasi persawahan dan lokasi pertambakan memiliki proporsi yang sama 
terhadap infeksi Eimeria sp. Hal tersebut berbeda dengan penelitian yang dilakukan oleh Hidayati dan Prastowo (2004) yang melaporkan bahwa prevalensi infeksi protozoa saluran pencernaan pada ayam betina lebih tinggi dibandingkan dengan ayam jantan kemungkinan disebabkan karena ayam betina hanya memiliki satu kromosom $\mathrm{Z}$ yang berpengaruh terhadap daya tahan tubuh, sehingga ayam betina lebih rentan terhadap infeksi protozoa saluran pencernaan. Sistem pemeliharaan dan kondisi lingkungan juga berpengaruh terhadap infeksi protozoa saluran pencernaan (Salfina, 1995). Di Desa Kramat ayam buras jantan dan betina tidak dipelihara terpisah, sehingga memiliki proporsi yang sama terhadap infeksi protozoa saluran pencernaan.

\section{Kesimpulan}

Berdasarkan hasil pemeriksaan terhadap 140 sampel feses ayam buras di Desa Kramat Kecamatan Bangkalan Kabupaten Bangkalan dapat disimpulkan bahwa jenis protozoa yang menginfeksi saluran pencernaan ayam buras di Desa Kramat Kecamatan Bangkalan Kabupaten Bangkalan adalah Eimeria acervulina (2,5\%), E. brunetti (22,8\%), E. maxima (46,8\%), E. mitis $(1,3 \%)$, E. necatrix $(22,8 \%)$, E. praecox $(2,5 \%)$, dan E. tenella (1,3\%). Prevalensi Eimeria sp. pada ayam buras di lokasi persawahan sebesar 22,9\% dan lokasi pertambakan sebesar 54,3\%. Prevalensi Eimeria sp. pada ayam buras jantan dan betina tidak berbeda masing-masing sebesar $34,35 \%$ dan $42,9 \%$.

\section{Daftar Pustaka}

Adhikari, A., R. Gupta, and R. Pant. 2008. Prevalence and Identification od Coccidian Parasite (Eimeria spp) in Layer Chicken of Ratnanagar Municipality, Chitwan District, Nepal. J. Nat. Hist. Mus. 23: 45-50.

Azmy, A.A., I.A.P. Apsari, dan I.B.K. Ardana. 2015. Isolasi dan Identifikasi Ookista Koksidia dari Tanah di Sekitar Tempat Pembuangan Sampah di Kota Denpasar. Indo. Med. Vet. 4(2): 163-169.

Badan Pusat Statistik Kabupaten Bangkalan. 2016. Kecamatan Bangkalan Dalam Angka 2016.https://bangkalankab.bps.go.id/websi te/pdf_publikasi/Kecamatan-Bangkalan-

\section{Dalam-Angka-2016.pdf. [23 Mei 2017].}

Bowman, D.D. 2014. Georgis' Parasitology for Veterinarians $10^{\text {th }}$ Ed. Elsevier. St. Louis. Missouri US. 97.

Gyorke, A., L. Pop, and V. Cozma. 2013. Prevalence and Distribution of Eimeria Species in Broiler Chicken Farm of Different Capacities. Parasite. 20: 50.

Hadipour, M.M., A. Olyaie, M. Naderi, F. Azad, and O. Nekouie. 2011. Prevalence of Eimeria Species in Scavenging Native Chickens of Shiraz, Iran. Afr. J. Microbiol. Res. 5(20). 3296-3299.

Hidayati, D.N. dan J. Prastowo. 2004. Tingkat Kejadian Infestasi Parasit Saluran Pencernaan pada Ayam Buras di Rumah Pemotongan Mbok Sabar dan Pasar Terban Yogyakarta. Buletin Peternakan. 28(1): 4246.

Jadhav, B.N. and S.V. Nikam. 2014. Study of Eimeria brunetti in Broiler Chicken from Aurangabad District of Maharashtra State India. Inter. J. App. Sci. 1(3):102-106.

Jamil, M., M. Mansoor, M.K. Khan, Amanullah, A. Khan, R.U. Haq, and F. Anwar. 2016. Prevalence of Coccidiosis in Broiler Chicken in District Dera Ismail Khan, Pakistan. J. Zool. Stud. 3(3): 41-45.

Kaboudi, K., S. Umar and M.T. Munir. 2016. Prevalence of Coccidiosis in Free-Range Chicken in Sidi Thabet, Tunisia. Scientifica. 16(10). 1-6.

Kimminau, E.A. 2015. Eimeria Species in Commerical Broiler Complexes in The United States. [Thesis]. Graduate Faculty of The University of Gergia.

Levine, N.D. 1995. Parasitologi Veteriner (terjemahan). Alih bahasa: Soekardono, S. Gadjah Mada University Press. Yogyakarta. 187; 321-323; 534-535; 537; 550.

Nagwa, E.A., L.M., El-Akabawy, R.S., El-Madawy and E.I., Toulan. 2013. Studies on Intestinal Protozoa of Poultry in Gharbia Governorate. Benha Vet. Med. J. 25(2): 7883. 